Vol 1, No 3, November 2020: 143-151, DOI: $\underline{10.34007 / \text { ins.v1i3.25 }}$

\title{
KEMAMPUAN BAKTERI ASAM LAKTAT DALAM MENGHAMBAT Salmonella thypii
}

\section{ABILITY OF LACTIC ACID BACTERIA IN INVENTION SaImonella thypii}

\author{
Rahmiati1)*, Helen Anjelina Simanjuntak2) \& Toberni S Situmorang3) \\ 1Universitas Medan Area, Indonesia \\ 2Sekolah Tinggi Ilmu Kesehatan Senior Medan, Indonesia \\ 3Universitas Efarina, Indonesia \\ Diterima: Februari 2019; Disetujui: Maret 2019; Dipublish: April 2019
}

*Coresponding Email: amirahmiati0405@gmail.com

\section{Abstrak}

Bakteri asam laktat diketahui memiliki kemampuan menghasilkan senyawa antimikroba yang dikenal sebagai bakteriosin. Penelitian ini bertujuan untuk melihat kemampuan bakteri asam laktat dalam menghambat pertumbuhan bakteri Salmonella thypii. Pada penelitian ini, bakteri asam laktat yang digunakan merupakan koleksi Laboratorium Biologi Universitas Medan Area. Delapan jenis isolat bakteri asam laktat yang digunakan antara lain IN01, IN02, SF01, SF02, NN01, NN02 SPU01 dan SPU04. Dilakukan uji konfirmasi terhadap pertumbuhan bakteri asam laktat dan Salmonella thypii dengan melakukan konfirmasi secara visual dan mikrokopis melalui pewarnaan diferensial. Hasil penelitian menunjukkan bahwa semua bakteri asam laktat merupakan kelompok bakteri gram positif berupa basil. Kelangsungan hidup isolat bakteri asam laktat di lingkungan dengan variasi pH dan kadar garam ditunjukkan dengan jumlah koloni yang tumbuh setelah masa inkubasi. Kemampuan antagonis bakteri asam laktat dalam menekan bakteri patogen dibuktikan dengan adanya zona hambat berupa daerah bersih di sekitar koloni patogen. Diketahui bahwa isolat bakteri SPU01 dan SF01 memiliki nilai zona hambat tertinggi yaitu 29,79 $\mathrm{mm}$ dan 28,13 $\mathrm{mm}$.

Kata Kunci: Bakteri Asam Laktat;Zona Hambat; Salmonella thypii

\begin{abstract}
Lactic acid bacteria are known to have the ability to produce antimicrobial compounds known as bacteriocins. This study aims to determine the ability of lactic acid bacteria to inhibit the growth of Salmonella thypii bacteria. In this study, the lactic acid bacteria used were a collection of the Biology Laboratory of the University of Medan Area. Eight types of lactic acid bacterial isolates were used, including IN01, IN02, SF01, SF02, NN01, NN02 SPU01 and SPU04. A confirmation test was carried out on the growth of lactic acid bacteria and Salmonella thypii by visual and microcopic confirmation through differential staining. The results showed that all lactic acid bacteria were a group of gram-positive bacteria in the form of bacilli. The survival of lactic acid bacterial isolates in the environment with variations in $\mathrm{pH}$ and salt levels was indicated by the number of colonies that grew after the incubation period. The antagonistic ability of lactic acid bacteria in suppressing pathogenic bacteria was proven by the presence of an inhibition zone in the form of a clean area around the pathogenic colony. It is known that the SPUO1 and SF01 bacterial isolates have the highest inhibition zone values, namely $29.79 \mathrm{~mm}$ and $28.13 \mathrm{~mm}$.
\end{abstract}

Keywords: Lactic Acid Bacteria; Inhibition Zone; Salmonella thypii

How to Cite: Rahmiati., Simanjuntak, H.A., \& Situmorang,T.S. (2020). Kemampuan Bakteri Asam Laktat Dalam Menghambat Salmonella thypii. Vol 1 (2): 143-151. 


\section{PENDAHULUAN}

Bakteri asam laktat merupakan kelompok bakteri gram positif yang tidak menghasilkan spora, termasuk ke dalam kelompok bakteri gram positif, memiliki kemampuan menghasilkan karbohidrat dan mampu menghasikan asam laktat. Terdapat 20 genera yang tergolong ke dalam kelompok bakteri asam laktat. Beberapa genus yang sering dimanfaatkan dalam industri makanan antara lain Aerococcus, Bifidiobacterium, Carnobacterium, Enterococcus, Lactobacillus, Lactococcus, Leuconostoc, Pediococcus, Streptococcus, Tetragenococcus, Weisella. Bakteri asam laktat termasuk ke dalam kelompok anaerob fakultatif, katalase negatif, variasi bentuk koloni basil dan kokus (Widodo, 2019; Aloysius et al, 2019).

Bakteri asam laktat dapat diisolasi dari berbagai sumber, antara lain makanan hasil fermentasi, minuman fermentasi, saluran pencernaan hewan, dan sayuran yang difermentasi. Bakteri asam laktat adalah bakteri yang aman dikonsumsi manusia dan termasuk dalam kategori GRAS (Generally Recognized as Safe). Prinsip kerja bakteri susu dalam fermentasi makanan bukanlah makanan busuk, melainkan fermentasi menggunakan dua mekanisme fermentasi yaitu homofermentatif dan heterofermentatif. Kelompok bakteri laktat homofermentatif hanya menghasilkan asam laktat sebagai produk utama dalam fermentasi gula, sedangkan kelompok heterofermentatif bakteri laktat menghasilkan asam laktat, karbondioksida, etanol dan asam asetat (Lestari \& Helmyati, 2018; Dewi et al, 2019).

Bakteri asam laktat telah diisolasi dari berbagai sumber diantaranya fermentasi ikan (Nurnaafi ,2015), saluran pencernaan unggas (Kadir, 2016), air susu ibu (Nuraida, 2011), fermentasi susu (Khedid \& Farid, 2006; Bukhori et al, 2020). Bakteri asam laktat diketahui memiliki kemampuan menghasilkan senyawa antimikroba yang disebut bakteriosin. Bakteriosin digunakan dalam aplikasi probiotik, sebagai pengawet dan sebagai alternatif dari antibiotik konvensional yang saat ini sedang dieksplorasi dan diselidiki secara ekstensif. Bakteriosin memiliki kapasitas bakterisidal atau bakteriostatik terhadap bakteri patogen. Bakterisidal diketahui sebagai senyawa yang dihasilkan oleh bakteri yang dapat membunuh bakteri lain. Bakteriosin sangat potensial untuk dikembangkan sebagai zat pengawet makanan karena sifatnya yang tidak berbahaya bagi kesehatan manusia dan dapat membunuh bakteri pembusuk serta patogen terhadap bahan pangan (Darma et al, 2004; Fachrial \& Harmileni, 2018). 
Bakteri asam laktat mampu menghambat mikroorganisme patogen baik bakteri dan jamur. Lunggani (2007), menyatakan bahwa bakteri asam laktat mampu menghambat pertumbuhan Aspergillus flavus dan produksi aflatoksin dari jamur tersebut. Kusumawati (2000) menyatakan bahwa isolat bakteri asam laktat mampu menghambat Lysteria monocytogenes yang mengkontaminasi bahan pangan. Gunawan et al (2018) menyatakan bahwa sebanyak 4 isolat bakteri asam laktat asal kefir memiliki kemampuan dalam menghambat pertumbuhan bakteri Staphylococcus aureus. Isolat bakteri asam laktat dari saluran pencernaan kepitng bakau diketahui memiliki aktivitas enzimatis dan diaplikasikan sebagai kandidat probiotik (Suciati et al, 2016).

Dewasa ini, potensi bakteri asam laktat sebagai penghasil senyawa antimikroba dan kandidat probiotik terus digali dan dikembangkan melalui tahapan isolasi, identifikasi, uji antagogis dan ekstraksi senyawa aktif. Salmonella thypii termasuk dalam kelompok mikroorganisme patogen yang menyerang sistem pencernaan. Berbagai penelitian dikembangkan untuk mengetahui potensi strain-strain bakteri dalam menekan pertumuhan bakteri tersebut, termasuk bakteri asam laktat. Penelitian ini bertujuan untuk mengetahui potensi bakteri asam laktat koleksi lokal Universitas Medan Area dalam menghambat Salmonella thypii.

\section{METODE PENELITIAN}

Penelitian dilaksanakan di Laboratorium Biologi Universitas Medan Area dan Laboratoirum Mikrobiologi Sekolah Tinggi Ilmu Kesehatan Senior Medan. Penelitian berlangsung pada bulan Januari sampai dengan Mei 2019.

\section{Konfirmasi Isolat Bakteri}

Isolat bakteri asam laktat merupakan koleksi Laboratorium Biologi Universitas Medan Area. Peremajaan isolat dilakukan dengan menumbuhkan isolat bakteri pada media de mangan sharpe rogosa agar (MRSA). Konfirmasi isolat dilakukan dengan melakukan pewarnaan diferensial untuk mengamati bentuk, penataan dan jenis bakteri.

Isolat bakteri patogen diperoleh dari RS. Adam Malik Medan. Bakteri Salmonella thypii ditumbuhkan dalam media salmonella-shigella agar (AAS). Diinkubasi selama 24 jam dan secara visual diamati pertumbuhan koloni bakteri. Konfirmasi isolat dilanjutkan dengan pertumbuhan dalam media simmon sitrat agar (SCA). Hasil tes yang positif terlihat dari perubahan warna pada bagian penyangga. 


\section{Viabilitas Bakteri Asam Laktat dalam Variasi Kadar Garam dan pH}

Viabilitas bakteri asam laktat pada $\mathrm{pH}$ dilakukan dengan membudidayakan kultur bakteri pada media MRS broth yang sebelumnya telah diatur pHnya yaitu 3,0; 2.5 dan 2.0. Selain itu diinkubasi selama 24 jam pada suhu 25-30 ${ }^{\circ}$ C. Sebanyak 0,1 ml suspensi Pada akhir masa inkubasi dihitung jumlah bakteri dengan metode total plate count pada media MRS agar. Sedangkan viabilitas terhadap kadar garam dilakukan dengan menumbuhkan $1 \mathrm{ml}$ kultur dalam bentuk suspensi berumur 24 jam ke dalam media MRS broth (MRSB) dengan penambahan garam empedu dengan konsentrasi $0,5 \% ; 1,0 \%$, $1,5 \% ; 2,0 \%$ dan 2,5\%. Selanjutnya diinkubasi selama 24 jam pada suhu $25-30^{\circ} \mathrm{C}$. Setelah 24 jam, sebanyak $1 \mathrm{ml}$ dari masing-masing media dengan variasi kadar garam tersebut diinokulasikan ke dalam media MRS agar (MRSA) dengan metode cawan tuang. Dilakukan perhitungan jumlah total bakteri dengan metode total plate count.

\section{Uji Antagonis Isolat Bakteri Asam Laktat dengan Salmolella thypii}

Uji antagonis dilakukan dengan metode difusi cakram pada media Mueller Hinton Agar. Suspensi bakteri Salmonella thypii dengan kerapatan sel $10^{8}$ koloni atau 0,5 OD dioleskan pada permukaan media uji. Sebanyak $10 \mathrm{ml}$ suspesi bakteri asam laktat diteteskan pada kertas cakram. Kertas cakram tersebut diletakkan pada kedua sisi media. Cawan uji diinkubasi pada suhu $25^{\circ}-30^{\circ} \mathrm{C}$ selama 24 jam. Parameter pengamatan yang diamati adalah pembentukan zona hambat berupa daerah jernih di sekitar cakram uji.

\section{Analisa data}

Data penelitian yang diperoleh dianalisis secara deskriptif dengan memaparkan hasil penelitian dalam tabulasi data.

\section{HASIL DAN PEMBAHASAN}

Sebanyak 8 isolat bakteri asam laktat diremajakan dalam media dan diamati karakteristik visual dan mikroskopisnya. Sumber isolat bakteri asam laktat bervariasi diantaranya dari saluran pencernaan ikan nila (IN01 dan IN02), minuman fermentasi (SF01 dan SF02), nira terfermentasi (NN01 dan NN02) dan saluran pencernaan udang (SPU01 dan SPU04). Isolat bakteri asam laktat dapat diperoleh dari berbagai sumber diantara lain susu fermentasi (yoghurt), sayuran fermentasi, saluran pencernaan hewan (sapi, ikan dan udang), fermentasi teh dan keju. 
Tabel 1. Konfirmasi karakteristik bakteri asam laktat

\begin{tabular}{lcccc}
\hline Isolat & $\begin{array}{c}\text { Viabilitas pada } \\
\text { media MRSA }\end{array}$ & Pewarnaan diferensial & Bentuk sel & Penataan sel \\
\hline IN01 & $\sqrt{ }$ & Gram positif & Basil & Mono-, staphylo- \\
IN02 & $\sqrt{ }$ & Gram positif & Basil & Mono-, strepto- \\
SF01 & $\sqrt{ }$ & Gram positif & Basil & Mono-, staphylo- \\
SF02 & $\sqrt{ }$ & Gram positif & Basil & Mono-, strepto- \\
NN01 & $\sqrt{ }$ & Gram positif & Basil & Mono-, diplo-, staphylo \\
NN02 & $\sqrt{ }$ & Gram positif & Basil & Mono-, staphylo- \\
SPU01 & $\sqrt{ }$ & Gram positif & Basil & Mono-, strepto- \\
SPU04 & $\sqrt{ }$ & Gram positif & Basil & Mono-, staphylo-
\end{tabular}

Kedelapan bakteri asam laktat yang diisolasi merupakan kelompok bakteri gram positif berupa basil (sel induk). Viabilitas bakteri di dalam media MRSA diketahui dengan adanya pertumbuhan koloni bakteri pada permukaan media. Bakteri asam laktat merupakan kelompok bakteri gram positif, tidak membentuk spora dan dapat memfermentasi karbohidrat, tidak dapat bergerak dan bersifat mikroaerofilik. Bentuk sel bakteri asam laktat bervariasi antara lain basil dan kokus.

Peremajaan isolat bakteri juga dilakukan untuk bakteri Salmonella thypii. Isolat tersebut ditumbuhkan dalam media agar Salmonella Shigella.. Konfimasi selanjutnya dilakukan dengan menumbuhkan di media simmons citrate agar (gambar 1).

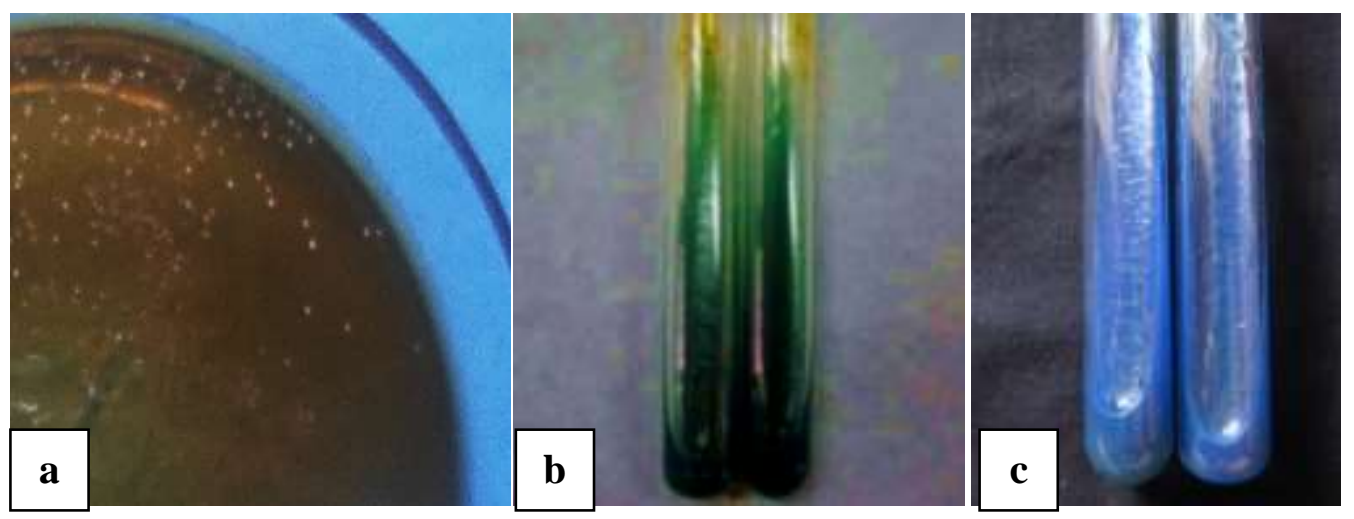

Gambar 1. Koloni Salmonella thypii di (a) media salmonella shigella agar; (b) media simmons citrate agar sebelum inkubasi dan (c) terjadi perubahan warna pada media simmons citrate agar (c).

Untuk mengetahui kemampuan bakteri dalam menggunakan sitrat sebagai sumber karbon dilakukan dengan uji sitrat. Media ini memiliki indikator BTB (Brom Tymol Blue). 
Saat bakteri menggunakan sitrat sebagai sumber karbon, pH medium berubah menjadi basa dan ditandai dengan perubahan warna dari hijau menjadi biru. Kemampuan bakteri menghidrolisis sutrat dikarenakan bakteri mengahasilkan enzim sitrat permease yang merupakan enzim spesifik yang membawa sitrat ke dalam sel.

Salmonella termasuk ke dalam famili enterobacteriaceae, merupakan bakteri gram negatif, memiliki flegella, bersifat anaerobik fakultatif dan berbentuk basil. Susu optimum untuk pertumbuhan bakteri ini pada $35^{0}-37^{\circ} \mathrm{C}$, tetapi beberapa serotipe mampu bertahan pada suhu $5^{\circ} \mathrm{C}$.

Tabel 2. Viabilitas dan jumlah total koloni bakteri asam laktat pada media dengan variasi $\mathrm{pH}$ dan kadar garam

\begin{tabular}{lcccccccc}
\hline \multirow{2}{*}{ Isolat } & $\mathrm{pH}$ & \multicolumn{7}{c}{ Kadar garam (\%) } \\
& 2.0 & 2.5 & 3.0 & 1 & 2 & 3 & 4 & 5 \\
\hline IN01 & - & 10 & 10 & 40 & 38 & 22 & - & - \\
IN02 & - & 15 & 28 & 30 & 25 & 18 & - & - \\
SF01 & - & 15 & 18 & 35 & 30 & 30 & - & - \\
SF02 & - & 10 & 15 & 55 & 40 & 15 & - & - \\
NN01 & - & 15 & 20 & 48 & 30 & 10 & - & - \\
NN02 & - & 20 & 25 & 38 & 30 & 20 & - & - \\
SPU01 & - & 15 & 20 & 40 & 33 & 30 & - & - \\
SPU04 & - & 10 & 30 & 50 & 42 & 35 & - & - \\
\hline
\end{tabular}

Berdasarkan Tabel 2 menunjukkan bahwa seluruh isolat bakteri asam laktat mampu hidup pada pH 2,5 dan 3 dengan jumlah total koloni bervariasi dari 10 hingga 30 colony forming unit. Selain mampu hidup pada $\mathrm{pH}$ rendah, bakteri asam laktat juga mampu hidup pada kondisi kadar garam tinggi. Berdasarkan tabel 2 diketahui bahwa rentang konsentrasi kadar garam yang dapat ditoleransi oleh bakteri asam laktat yaitu dengan konsentrasi kadar garam 1\%-3\% . Pada media dengan konsentrasi kadar garam $20 \%$ dan 25\%, diketahui tidak ada bakteri yang tumbuh.

Resistensi bakteri asam laktat terhadap kadar garam merupakan karakteristik penting mengingat peran bakteri asam laktat sebagai probiotik. Kemampuan ini digunakan oleh bakteri asam laktat untuk bertahan dan berkembang di usus saat terkena garam empedu. Bakteri asam laktat dapat menghasilkan enzim hidrolase garam empedu yang dapat menghidrolisis garam empedu sehingga tidak beracun bagi bakteri asam laktat. Argyri et al (2013) menyatakan bahwa, bakteri asam laktat memiliki ketahanan tinggi terhadap pH dan garam empedu lebih dari 50\%. 
Tabel 3. Kemampuan bakteri asam laktat dalam menghambat Salmonella thypii

\begin{tabular}{|c|c|c|c|c|}
\hline \multirow[t]{2}{*}{ Isolat } & \multicolumn{3}{|c|}{ Nilai zona hambat (mm) } & \multirow[b]{2}{*}{ Rata - rata } \\
\hline & $\overline{\mathrm{U} 1}$ & $\mathrm{U} 2$ & U3 & \\
\hline IN01 & 17,65 & 18,02 & 16,50 & 17,39 \\
\hline IN02 & 9,75 & 10,50 & 10,05 & 10,10 \\
\hline SF01 & 28,00 & 27,65 & 28,75 & 28,13 \\
\hline SF02 & 11,56 & 12,45 & 13,00 & 12,33 \\
\hline NN01 & 08,00 & 07,87 & 09,00 & 08,29 \\
\hline NN02 & 18,00 & 21,00 & 19,25 & 19,41 \\
\hline SPU01 & 30,00 & 28,38 & 31,00 & 29,79 \\
\hline SPU04 & 08,85 & 09,00 & 10,05 & 09,30 \\
\hline
\end{tabular}

Kemampuan bakteri asam laktat dalam menghambat Salmonella thypii ditunjukkan dengan zona hambat yang dihasikan dalam bentuk daerah jernih di sekitar koloni patogen (Gambar 2). Pengujian kemampuan antagonis ini dilakukan dengan metode difusi cakram. Seluruh isolat bakteri asam laktat yang diujikan memiliki kemampuan dalam menghambat pertumbuhan Salmonella thypii dengan diameter yang bervariasi. Isolat bakteri asam laktat SPU01 dan SF01 diketahui menghasilkan zona hambat terbesar dengan nilai zona hambat masing - masing yaitu sebesar 29,79 $\mathrm{mm}$ dan 28,13 mm. Perbedaan kemampuan zona hambat yang dihasilkan disebabkan oleh bebererapa hal diantaranya umur dan jenis bakteri asam laktat, jenis mikroorganisme patogen, waktu inkubasi, kemampuan inhibisi senyawa antimikroba ke media dan komposisi media.

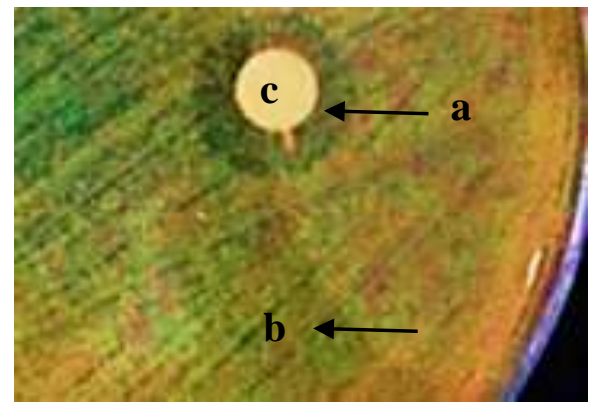

Gambar 2. Zona hambat yang dihasilkan oleh isolat bakteri asam laktat SPU01 (a). zona jernih; (b) bakteri Salmonella thypii dan (c) disc uji

Variasi zona hambat yang dihasilkan oleh bakteri asam laktat diketahui lebih rendah dibandingkan dengan hasil pegujian bakteri asam laktat terhadap kontrol (antibiotik komersil). Zona hambat yang dihasilkan oleh kontrol yaitu sebesar 60,50 mm. Kloramfenikol digunakan sebagai antibiotik kontrol. Isolat bakteri asam laktat yang dikumpulkan dari lapangan di Universitas Medan mampu menghambat pertumbuhan Salmonella thypii, namun zona hambatnya lebih rendah dari pada antibiotik komersial. 


\section{SIMPULAN}

Delapan jenis isolat bakteri asam laktat ampu menghambat pertumbuhan

Salmonella thypii dengan niai zona hambat yang bervariasi. Nilai zona hambat terbesar ditunjukkan oleh isolat bakteri SPU01 dan SF01.

\section{DAFTAR PUSTAKA}

Aloysius, A., Ulfa, A., Situmorang, A., Harmileni, H., \& Fachrial, E. (2019). AKTIVITAS ANTIMIKROBA BAKTERI ASAM LAKTAT YANG DIISOLASI DARI MAKANAN TRADISIONAL FERMENTASI KHAS BATAK “NANIURA”. BIOLINK : Jurnal Biologi Lingkungan Industri Kesehatan, 6(1), 8 - 15.

Bukhori, A., Sartini, S., \& rahmiati, R. (2020). Isolasi Bakteri Asam Laktat (BAL) dari Saluran Pencernaan Ikan Nila (Oreochromis niloticus) dan Kemampuannya Dalam Menghambat Staphylococcus aureus dan Shigella sp.. Jurnal Ilmiah Biologi UMA (JIBIOMA), 2(1), 23-31.

Dewi, L., Sartini, S., \& Rahmiati, R. (2019). Isolasi Bakteri Asam Laktat dari Usus Sapi (Bos taurus) serta Kemampuannya dalam Menghambat Pertumbuhan Bakteri Eschericia coli dan Shigella sp. Jurnal Ilmiah Biologi UMA (JIBIOMA), 1(1), 21-27.

Fachrial, E., \& Harmileni, H. (2018). ISOLASI DAN AKTIVITAS ANTI MIKROBA BAKTERI ASAM LAKTAT DARI FERMENTASI NIRA KELAPA SAWIT. BIOLINK : Jurnal Biologi Lingkungan Industri Kesehatan, 5(1), 51-58.

Gunawan AA, Dewi SS \& Wilson W. (2018). Aktivitas Kefir dan Isolat Bakteri Asam Laktat dari Kefir dalam Menghambat Pertumbuhan Staphylococcus Aureus. Prosiding Seminar Nasional Mahasiswa Unimus. 1(1): $190-196$

Kadir IK. (2016). Pertumbuhan Bakteri Asam Laktat (BAL) Kandidat Probiotik Asal Saluran Pencernaan Broiler terhadap Berbagai Kondisi Asam Lambung. Jurusan Ilmu Peternakan Fakultas Sains dan Teknologi Universitas Islam Negeri Alauddin Makassar

Khedid K \& Faid M. (2006). Characterization of Lactic Acid Bacteria Isolated from the One Humped Camel Milk Produced in Morocco. Microbiology Reseach. 164(5): 81 - 91

Kusumawati N. (2000). Peranan Bakteri Asam Laktat dalam Menghambat Listeria monocytogenes pada Bahan Pangan. Jurnal Teknologi Pangan dan Gizi. 1(1): 14 - 29

Lestari \& Helmyati. (2018). Peran Probiotik di Bidang Gizi dan Kesehatan. Gadjah Mada University Press: Yogyakarta.

Lunggani AT. (2007). Kemampuan Bakteri Asam Laktat dalam Menghambat Pertumbuhan dan Produksi Aflatoksin B2 Aspergilllus flavus Arina Tri Lunggani. Bioma. 9 (2): 45 - 51.

Nuraida L, Winarti S, Hana \& Prangdimurti E. (2011). Evaluasi in Vitro terhadap Kemampuan Isolat Bakteri Asam Laktat Asal Air Susu Ibu untuk Mengasimilasi Klestrol dan Mendekonjugasi Garam Empedu. Jurnal Teknol dan Industri Pangan. 22(1): 46 - 52

Nurnaafi A, Setyaningsih I \& Desniar. (2015). Potensi Probiotik Bakteri Asam Laktat Asal Bekasam Ikan Nila. Jurnal Teknol dan Industri Pangan. 26(1): 109 - 114

Suciati P, Thajjaningsih W, Masithah ED \& Pramono H. (2016). Aktivitas Enzimatis Isolat Bakteri Asam Laktat dari Saluran Pencernaan Kepiting Bakau (Scylla spp.) Sebagai Kandidat Probiotik. Jurnal Perikanan dan Kelautan. 8(2): 94 - 108

Widodo. (2019). Bakteri Asam Laktat Strain Lokal. Gadjah Mada University Press: Yogyakarta. 